\title{
The Problem of Traditional African Pharmacopoeia in Obstetrics: Use of Plants for Utero-Tonic Purposes and Materno-Fetal Outcome in Douala (Cameroon)
}

\author{
Essome Henri1,2*, Mve Koh Valere ${ }^{3,4}$, Nana Njamen Theophile ${ }^{5,6}$, Boten Merlin'2, \\ Ekono Michel Roger ${ }^{1}$, Penda Ida Calixte ${ }^{1,2}$, Tocki Toutou Grâce ${ }^{2}$, Halle Ekane Gregory5,6, \\ Foumane Pascal 3,7 , Mboudou Emile Telesphore ${ }^{3,8}$ \\ ${ }^{1}$ Faculty of Medicine and Pharmaceutical Sciences of Douala, University of Douala, Douala, Cameroon \\ ${ }^{2}$ Laquintinie Hospital of Douala, Douala, Cameroon \\ ${ }^{3}$ Faculty of Medicine and Biomedical Sciences of Yaounde, University of Yaounde, Cameroon \\ ${ }^{4}$ Yaoundé Teaching Hospital, Yaounde, Cameroon \\ ${ }^{5}$ Faculty of Health Sciences of Buea, University of Buea, Buea, Cameroon \\ ${ }^{6}$ Douala General Hospital, Douala, Cameroon \\ ${ }^{7}$ Yaoundé Gyneco-Obstetrics and Pediatric Hospital, Yaounde, Cameroon \\ ${ }^{8}$ Gyneco-Obstetric and Pediatric Hospital of Douala, Douala, Cameroon \\ Email: ^essometocky@yahoo.com
}

How to cite this paper: Henri, E., Valere, M.K., Theophile, N.N., Merlin, B., Roger, E.M., Calixte, P.I., Grâce, T.T., Gregory, H.E., Pascal, F. and Telesphore, M.E. (2019) The Problem of Traditional African Pharmacopoeia in Obstetrics: Use of Plants for Utero-Tonic Purposes and Materno-Fetal Outcome in Douala (Cameroon). Open Journal of Obstetrics and Gynecology, 9, 1464-1476.

https://doi.org/10.4236/ojog.2019.911142

Received: October 8, 2019

Accepted: November 8, 2019

Published: November 11, 2019

Copyright $\odot 2019$ by author(s) and Scientific Research Publishing Inc. This work is licensed under the Creative Commons Attribution International License (CC BY 4.0).

http://creativecommons.org/licenses/by/4.0/

\begin{abstract}
Introduction: The use of traditional preparations for the induction or acceleration of labor remains a common practice in our country in particular and in Africa in general with sometimes derogatory outcomes for the mother and the fetus. Goal: The objective was to assess immediate maternal and neonatal outcomes in women who reported having used the traditional pharmacopoeia for utero-tonic purposes. Methodology: We conducted a multi-centric crosssectional study with prospective data collection in the maternities of the Laquintinie Hospital, Bonassama District and Nylon Hospitals. It took place over a period of seven months, from 1st October 2016 to 31st April 2017. This included all women who reported having used the unconventional pharmacopoeia for utero-tonic purposes before or after contractions started. The student and Chi-square tests were interpreted at the statistical threshold of 5\% and the $95 \%$ confidence intervals. Results: We recruited 168 cases, $68.5 \%$ of the 245 women interviewed. The mean age was $27.1 \pm 0.41$ years; $55 \%$ of our respondents had a secondary level of education; $80 \%$ of them were admitted at term and $43 \%$ were multiparous. Nulliparity predisposed to traditional pharmacopoeia use $(\mathrm{RR}=1.55, \mathrm{CI}=0.79-3.03)$ but primiparity reduced this
\end{abstract}


risk $(\mathrm{RR}=0.4, \mathrm{CI}=0.24-0.926)$. Stimulation of labor was the first indication in $85 \%$ of women, the rectal evacuation enema was the main route used (67\%). The majority of plants used were those of the families Asteraceae, Anthericaceae, and Malvaceae. In per partum, $42 \%$ had a brilliant dilatation; there was a statistically significant association between the occurrence of dynamic dystocia $(\mathrm{CI}=0.28-1.54, \mathrm{p}=0.006)$ and the risk of perineal tear $(\mathrm{RR}=$ $3.13, \mathrm{CI}=1.68-5.85 ; \mathrm{p}=0.007)$. The APGAR score at $5 \mathrm{~min}$ of life was less than 7 in $64 \%$ of cases $(p=0.027)$. The caesarean section rate was $69 \%$. Conclusion: Traditional products with uterotonic effects are frequently used and unregulated with its corollary of materno-fetal complications.

\section{Keywords}

Utero-Tonic Plants, Hyperkinesia, Fetal Distress, Caesarean Section

\section{Introduction}

The relations between plants and men have existed since antiquity [1]. Plants, vital components of biological diversity, are used primarily for human well-being. In Africa, the use of medicine and traditional pharmacopoeia is very common in the countryside and even in urban areas. This situation could be explained by the poverty of the populations, the insufficiency of infrastructures and personnel in modern medicine, but also by religious or superstitious considerations [2]. Despite the progress of Western medicine, few people in Africa have taken a step back from traditional medicine. It provokes infatuation among the population at all levels because it is the secretion of our socio-cultural milieu. Africans, regardless of their social status or level of education, remain attached to their traditions and often resort to it whenever the need arises. Cosmogonic perceptions and religious beliefs reinforce this trend. As a result, the belief in the harmlessness of medicinal plants because of their natural origin makes them an alternative to conventional therapy [3]. In the United States, some pregnant women use Calophyllum thalictroides for its utero-tonic effect [4]. In China, traditional herbal preparations account for between $30 \%$ and $50 \%$ of drug consumption [5]. In France, Sophie Barbelet demonstrated the utero-tonic effect of the essential oil of Syzigium aromaticum [6]. In Ivory Coast, KoffiN'guessan et al. in 2010 highlighted the use of 34 plant species, to facilitate childbirth [7]. Studies in South Africa estimated that between $43 \%$ and $55 \%$ of women used traditional oxytocics during pregnancy [8].

Another study in Nigeria found that $62 \%$ of women surveyed had used herbal medicines during pregnancy [9]. In Kenya and Ghana, traditional birth attendants provided herbal medicines to women during pregnancy or delivery for their utero-tonic effects [10] [11]. The fact that traditional medicines can have utero-tonic effects is an important aspect of public health [12]. Studies in Malawi and Uganda have suggested that traditional medicines may be involved in a sig- 
nificant proportion of maternal deaths [13] [14]. Other studies have suggested that herbal medications may be involved in maternal and fetal adverse events such as uterine rupture or foetal asphyxia [15] [16]. In Cameroon, several studies have been conducted including those of: Esther Ngadjui et al. in March 2013, on the in vitro evaluation of the utero-tonic activity of Ficusasperifolia extract in rats. It had found a similar utero-tonic activity to that of oxytocin [17]. KidikPouka et al. in a study conducted in 2015 highlight the use by populations of flavonoid plants to facilitate childbirth [18]. Ngene et al. in 2015 identify plants used to facilitate deliveries [19]. It is in this context that we conducted this study on the different plants and utero-tonic substances of informal use in maternity of hospitals in Douala, to appreciate the materno-foetal outcome and hope to contribute to the improvement of knowledge on this pharmacopoeia.

\section{Methods}

This was a multicentric cross-sectional study with prospective data collection conducted at Laquintinie Hospital in Douala and at Bonassama and Nylon District Hospitals over a seven-month period from October 1st, 2016 to April 31st, 2017. This included any woman who reported having used an unconventional pharmacopoeia for utero-tonic use as a self-medication before or after the onset of uterine contractions. A standardized form was submitted to them and then a survey in nature with visual identification of the substance was carried out for determination of the scientific name. This form included, in addition to the names of the plants, the sociodemographic, gestational and clinical variables collected in the records of the deliveries. The evaluation of uterine contractions (UC) was done by external tocography to record intensity, frequency and duration of the UCs. The operational definitions were:

- hyperkinesia of frequency: $>5 \mathrm{UC} / 10 \mathrm{~min}$;

- hyperkinesia of intensity: $>80 \mathrm{mmHg}$ at the tocograph or $>3+++$ by manual method;

- excluded were those having benefited from conventional oxytocics or having benefited from a mixture of conventional oxytocics and medicinal plants.

\section{- Sampling}

We proceeded to a consecutive recruitment of the pregnant women for the study with a basic sample set at 245 .

$$
n=z^{2} P(1-P) / d^{2}
$$

So, $n=245$.

$P=80 \%$ study done on the use of medicinal plants in Africa [20].

\section{- Procedure}

After obtaining the various research authorizations from the directors of the Laquintinie Hospital of Douala, Bonassama District and Nylon District Hospitals, and the Ethics and Institutional Committees, we proceeded on the one hand to the recruitment of parturients and post-partums, on the other hand, the harvesting of plant samples. 
The recruitment procedure concerned parturient in the delivery room, postpartum deliveries as well as postoperative caesarean section women meeting the eligibility criteria, followed by the collection of data in the collection form preconceived for the study.

Prospecting and harvesting of the plant material consisted of the presentation of the samples to the interviewees for validation before their deposit at the Cameroonian national herbarium to obtain the scientific names.

The therapeutic properties of these plants were determined using documentation related to the work on phytochemical screening.

The data obtained was entered and processed with CSPRO 6.2, Microsoft Excel 2010, and SPSS version 20 software, and expressed as frequencies, averages and proportions. Statistical analyses were performed, with the student t-test used for quantitative variables and Chi 2 tests for qualitative variables, with a statistical threshold of $\mathrm{p} \leq 0.05$ and $95 \%$ confidence intervals; all parturient signed a consent form.

\section{Results}

We included 168 deliveries out of 245 surveyed (77 respondents reported using made-up plants and bark that we could not record), a frequency of $68.5 \%$ of our deliveries. The mean age was $27.17 \pm 0.41$ years with extremes of 16 and 43 years and a peak in the range of $23-32(69 \%)$. Our study population was predominantly married (42\%), with a secondary level of education (54\%) and an income generating activity (70\%) (Table 1).

Table 1. Sociodemographic variables.

\begin{tabular}{|c|c|c|c|}
\hline Variables & Category & Frequency & $(\%)$ \\
\hline \multicolumn{4}{|c|}{$N=168$} \\
\hline \multirow{3}{*}{ Age } & $16-22$ & 27 & 16 \\
\hline & $23-32$ & 115 & 69 \\
\hline & $33-43$ & 26 & 15 \\
\hline \multirow{4}{*}{ Level of education } & Uneducated & 5 & 3 \\
\hline & Primary & 11 & 7 \\
\hline & Secondary & 92 & 54 \\
\hline & University & 60 & 36 \\
\hline \multirow{2}{*}{ Income generating activity } & Yes & 118 & 70 \\
\hline & No & 50 & 30 \\
\hline \multirow{5}{*}{ Marital status } & Married & 70 & 42 \\
\hline & Single & 50 & 30 \\
\hline & Concubine & 45 & 27 \\
\hline & Divorced & 1 & 0.6 \\
\hline & Widow(er) & 2 & 1.2 \\
\hline
\end{tabular}


Many of them were in their first use (52\%) and 54\% had a favorable and healthy opinion of this practice (Table 2); $80 \%$ of them were admitted at term and $43 \%$ were multiparous. Nulliparity predisposed to traditional pharmacopoeia use $(\mathrm{RR}=1.55, \mathrm{CI}=0.79-3.03)$, but primiparity reduced this risk $(\mathrm{RR}=0.4, \mathrm{CI}=$ $0.24-0.926$ ) (Table 3 ). Stimulation of labor was the primary indication for $85 \%$ of women (Table 4).

The maternal survey identified 22 plants used for supposed utero-tonic effects and hibiscus was the most commonly used, 25\% of cases (Figure 1). Leaves were the most commonly used plant parts in the plant in $75 \%$ (Figure 2) prepared mainly by maceration (Figure 3 ) and a use most often by rectal enema evacuator (Figure 4).

This use exposed some of them to pejorative consequences with statistically significant incidences of $42 \%$ of brilliant dilatations (70 cases) with labor time < 4 h (OR: 1.45 ; IC: $0.35-2.68) \mathrm{p}=0.00028 ; 70 \%$ (117 cases) of intensity hyperkinesia (OR: 1.27; IC: $0.79-1.08) \mathrm{p}=0.001 ; 33 \%$ (55 cases) of dynamic dystocia (OR: 1.10; IC: 0.28 - 1.52) $\mathrm{p}=0.006$; a high rate of caesareans, $69 \%$ (116 cases) (OR: 1.11 ; IC: $0.26-5.49) \mathrm{p}=0.007$ with $64 \%$ (112 cases) of newborns with a poor Apgar score at the 5th minute of life (OR: 1.14; IC: $0.3-11.13$ ) $\mathrm{p}=0.027$ and $45 \%$ (75 cases) perineal tears (OR: 3.13: CI: $1.68-5.85) \mathrm{p}=0.007$ (Table 5).

Table 2. Perception of the participants about the use.

\begin{tabular}{cccc}
\hline Variable & Responses & Frequency & $\%$ \\
\hline Opinion on the use of & Saine & 90 & 54 \\
traditional utero-tonics & Dangereux & 78 & 46 \\
\hline Utilisation antérieure & Oui & 80 & 48 \\
& Non & 88 & 52 \\
\hline
\end{tabular}

Table 3. Risk of use and parity.

\begin{tabular}{|c|c|c|c|c|c|c|c|}
\hline & \multicolumn{2}{|c|}{ Yes } & \multicolumn{2}{|c|}{ No } & \multirow{2}{*}{$\mathbf{P}$} & \multirow{2}{*}{$\mathrm{RR}$} & \multirow{2}{*}{ CI $95 \%$} \\
\hline & $N=168$ & $\%$ & $N=77$ & $\%$ & & & \\
\hline Nulliparous & 30 & 18 & 24 & 31 & $0.039^{*}$ & 1.55 & $0.79-3.03$ \\
\hline Primiparous & 66 & 39 & 16 & 21 & $0.020^{*}$ & 0.47 & $0.24-0.926$ \\
\hline Multiparous & 72 & 43 & 37 & 48 & 0.571 & & \\
\hline
\end{tabular}

Table 4. Obstetricalcharacteristics.

\begin{tabular}{cccc}
\hline & Variable & $\mathrm{N}=168$ & $\%$ \\
\hline \multirow{2}{*}{ Gravid formula } & Nulliparous & 30 & 18 \\
& Primiparous & 66 & 39 \\
& Multiparous & 72 & 43 \\
\hline \multirow{2}{*}{ Term of use (weeks) } & $37-39$ & 110 & 65 \\
\hline Indication & $39-41$ & 58 & 35 \\
\hline & Induction & 26 & 15 \\
\hline
\end{tabular}


Table 5. Materno-fotal complications.

\begin{tabular}{|c|c|c|c|c|c|c|c|}
\hline \multirow{2}{*}{$\begin{array}{c}\text { Use of } \\
\text { traditional } \\
\text { utero-tonics }\end{array}$} & \multicolumn{2}{|c|}{ Yes } & \multicolumn{2}{|c|}{ No } & \multirow[b]{2}{*}{$\mathrm{RR}$} & \multirow[b]{2}{*}{ CI 95\% } & \multirow[b]{2}{*}{$\mathrm{p}$} \\
\hline & $\mathbf{N}$ & $\%$ & $\mathbf{N}$ & $\%$ & & & \\
\hline $\begin{array}{l}\text { Complications } \\
\text { during first use }\end{array}$ & 156 & 93 & 12 & 7 & 0.40 & $0.23-0.97$ & 0.0001 \\
\hline $\begin{array}{l}\text { Duration of labor } \\
\leq 4 \mathrm{~h}\end{array}$ & 70 & 42 & 98 & 58 & 1.45 & $0.35-2.68$ & 0.0028 \\
\hline $\begin{array}{l}\text { Hyperkinesia } \\
\text { of frequency }\end{array}$ & 125 & 75 & 43 & 25 & 0.96 & $0.79-2.68$ & 0.041 \\
\hline $\begin{array}{l}\text { Hyperkinesia } \\
\text { of intensity }\end{array}$ & 117 & 70 & 51 & 30 & 1.27 & $0.79-1.08$ & 0.001 \\
\hline Fœtal distress & 107 & 64 & 61 & 36 & 0.45 & $0.87-2.64$ & 0.037 \\
\hline $\begin{array}{l}\text { Dynamic } \\
\text { dystocia }\end{array}$ & 55 & 33 & 113 & 67 & 1.10 & $0.28-1.52$ & 0.006 \\
\hline $\begin{array}{l}\text { Caesarienne } \\
\text { section }\end{array}$ & 115 & 69 & 53 & 31 & 1.11 & $0.26-5.49$ & 0.007 \\
\hline $\begin{array}{l}\text { Poor Apgar et } \\
5 \text { th min }\end{array}$ & 112 & 66 & 56 & 34 & 1.24 & $0.3-11.13$ & 0.027 \\
\hline Perinealtear & 65 & 39 & 103 & 61 & 3.13 & $1.68-5.85$ & 0.007 \\
\hline
\end{tabular}

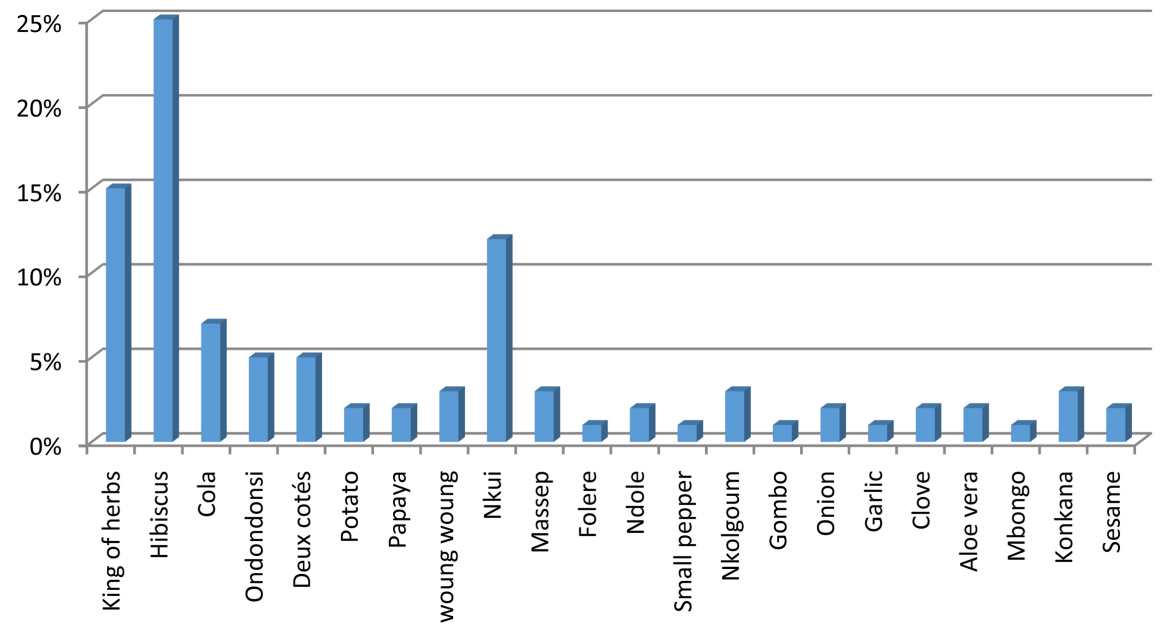

Figure 1. Frequency of use of the different plant.

\section{Discussion}

\section{1) Prevalence}

In our study, we recorded 168 women who admitted to using an utero-tonic plant (68.57\%). This prevalence is similar to that obtained in Nigeria by Olusanyo et al. in 2010 (62\%) [9], from Titilayo et al. in 2009 (68\%) [21]. However, it is higher than those obtained by Mothupi et al. in Kenya in 2014 (12.5\%) [22], Nyeko et al. in 2016 in Uganda (20\%) [23]. The prevalence of the use of plants and substances for utero-tonic purposes is variable in the literature and is explained by the variability of crops, study environments and indications. 


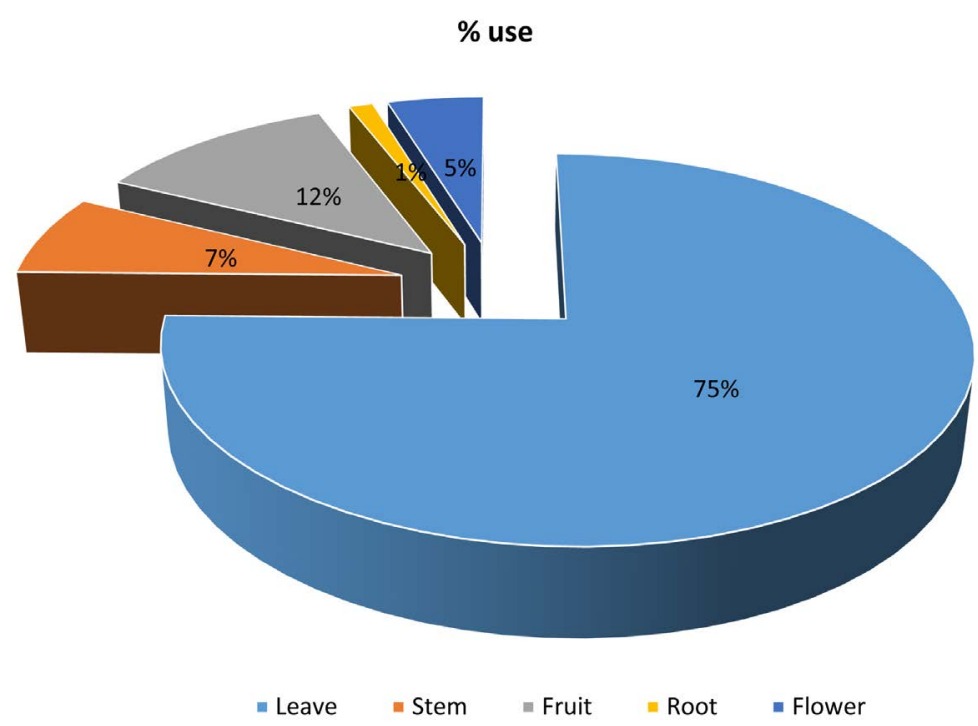

Figure 2. Plant parts mainly used.

\section{Mode of preparation}

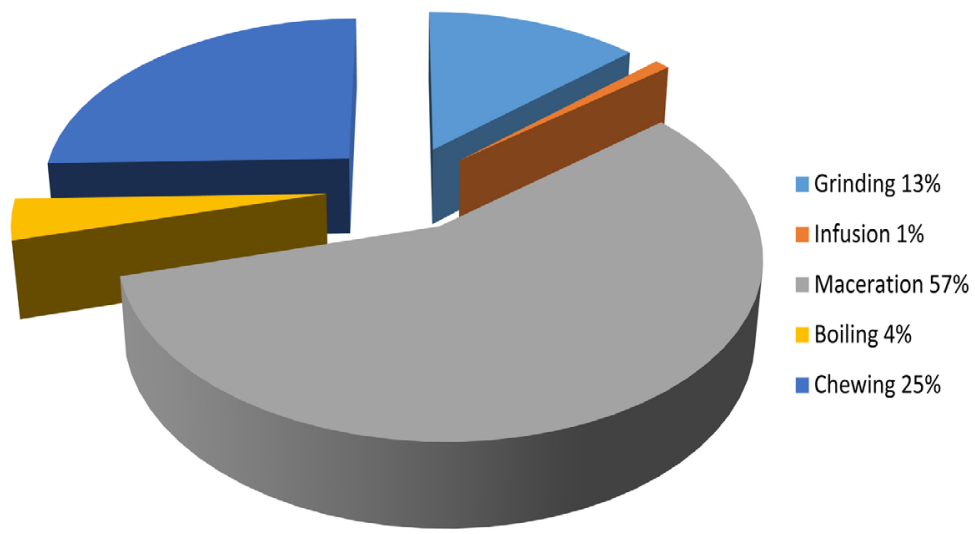

Figure 3. Declared mode of preparation.

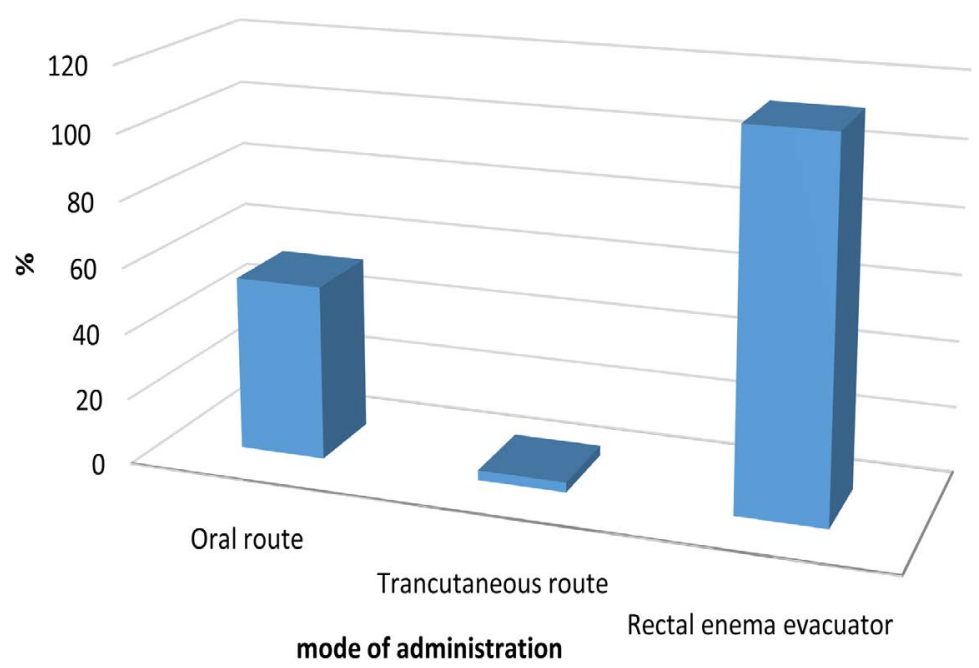

Figure 4. Mode of administration. 


\section{2) Socio-demographic characteristics}

- Age: The average age in our series was 27.17 years, with extremes of 16 and 43 years old. These results are similar to those of Nyeko et al. in Uganda in 2016 (25.32 years) [22]; Aka et al. in Ivory Coast in 2016 (26.55 years, 17 - 35 years) [24]; Dika et al. in 2017 in Tanzania (26.6 years old) [25]. These age groups correspond to the physiological phase of reproduction of women.

- Parity: Multiparas were the majority (72 women, $43 \%$ ), followed by primiparas (66 women, 39\%) and nulliparas (30 women, 18\%). These results are similar to those of Nyeko et al. In 2016 in Uganda (multiparas 22, 6\%; primiparas 12.6\%) [22]. However, they contrast with those of Aka et al. 2016 in Ivory Coast (nulliparous 51.42\%, primiparas 18.57\%, multiparous 10\%) [24].

- Educational level: The population of our series consisted mainly of seconday school (55\%) and university (36\%) levels. This result differs from that of Nyeko et al. in 2016 in Uganda (secondary level 20\%) [22].

- Term of use: In the same way as the data from the literature, the use of utero-tonic plants exclusively concerned the third trimester of pregnancy in our sample. These results are similar to those obtained by Aka et al. in 2016 in Ivory Coast (100\% 3rd trimester) [24], Kamatenesi et al. 2007 in Uganda (91\% in the 3rd trimester) [26]; Astin et al. in 1996 in Malaysia (80\% in the 3rd trimester) [27]. However, these results contrast with those obtained by Nyeko et al. in Uganda in 2016 (2nd trimester 23.1\%, 3rd trimester 20.5\%) [23].

The variability in the period of use of plants in pregnancy can be explained by the difference in purpose and objective of use.

\section{3) Factors associated with the use of plants}

- Parity had a statistically significant difference. Nulliparas were more likely to use them than primiparas or multiparous. These results are consistent with those of Nyeko et al. 2016 in Uganda [23], where a statistically significant difference was found in terms of parity. However, these results contrast with those of Aka et al. 2016 in Ivory Coast [24], where no statistically significant difference was found.

\section{4) Indications}

The plants were used to facilitate deliveries. Two main indications emerged: Induction $15 \%$ and stimulation $85 \%$. These results corroborate those obtained by Azriani et al. in 2008 [28] in Malaysia and M'soka et al. 2015 in Zambia [29] who found stimulation as their first indication (78\%, 89.9\%); Dika et al. in 2017 in Tanzania (88\%) [25]; Rolanda et al. in 2006 in South Africa report the use of plants to increase uterine tone [30].

\section{5) Route of administration}

The rectal evacuation enema was the primary mode of utero-tonic use (67\%), followed by oral (31.5\%) and transcutaneous (1.5\%). These results are similar to those of Aka and al in 2016 in Côte d'Ivoire, where the rectal route was mostly used (51.41\%) [24]. 
However, other authors report a predominance of the oral route. Report made by: N'guessan et al. in 2010 in Côte d'Ivoire (oral route 45.23\%, enema 42.85\%) [7]; Nyeko et al. in Uganda in 2016 (69.2\% oral, 19.36\% skin application) [23]. This discrepancy, in our opinion, is due to the cultural disparity of the surveyed communities.

6) Complications

Both maternal and fetal complications were observed when utero-tonic plants were taken in our series. Frequency hyperkinesia, intensity hyperkinesia, fetal distress, dynamic dystocia, an APGAR score of less than 7, brilliant dilatation, and perineal tears showed a statistically significant difference. The immediate consequence was a doubling of the number of caesareans with a frequency of $69 \%$ and the duration of labor influenced the mode of delivery. These results are similar to those obtained by Aka et al. in Côte d'Ivoire in 2016, who had foetal heart rate abnormalities, dynamic dystocia and a caesarean section frequency of 68.57\% [24]; Ezechi et al. in Nigeria in 2004 who found uterine rupture complications [31]; Guerrier et al. in 2013 in Nigeria and Johnson et al. in 2009 in Nigeria revealed the occurrence of neonatal asphyxia [32] [33].

7) Plants and substances

a) Floristic inventory: During this study, we identified 22 plants belonging to 16 botanical families. This result differs from that of Nguessan et al. in 2010, with 34 plants belonging to 24 families [7]. In contrast to Nguessan whose study was rural, our study was based on the urban environment.

b) Botanical family: The listed plants belonged mostly to families: Asteraceae, Anthericaceae, Malvaceae. Nguessan et al. in 2010 in Ivory Coast found Euphorbiaceae and Fabaceae mainly [7]. However, there are similarities in the families Asteraceae, Euphorbiaceae, Zingiberaceae. This is because tropical plants are common to most of sub-Saharan Africa. This variability is due to the different methods of investigation (localities and vegetation).

c) Plant part: The most used part was the leaf (75\%), followed by fruits (12\%), and finally stems (7\%). This result is consistent with that obtained by Ngene et al. in 2015 [19] in an ethnobotanical survey in the city of Douala (52\%). However, this result contrasts with those obtained by Nguessan et al. in 2010 [7] where stems and their bark were mostly used (45.92\%). This is because our plants were mostly herbaceous with easy access to the leaves. Unlike the Ivorian study where the predominance of trees was noted making it difficult to access the leaves.

d) Mode of preparation: Maceration is the most popular method of preparation (57\%), followed by chewing (25\%) and grinding (13\%). This result is close to that established by Adjanohoun and Aké Assi (1979). However, this result contrasts with that of Nguessan et al. in 2010 in an ethnobotanical study had found kneading (69.70\%) [7]. This is explained by the fact that in our study the most used vegetable part was the leaves whose maceration is the best mode of extraction. Nguessan et al. 2010 had found the bark whose best extraction is kneading [7]. 
e) Secondary metabolites: The plants resulting from our investigation and which were used for their utero tonic effect by the parturient are globally flavonoids and alkaloids. These results corroborate those of N'guessan et al. in Ivory Coast 2009 [34]: flavonoids of the flavanone type, indole alkaloids and pyrrolizidine alkaloids (Nacoulma 1996) have utero-tonic effects; Gruber et al. 2011 reveals that certain chemical compounds found in plants have the potential to trigger uterine contractions [35].

f) Plants and studies: Of the plants in the study, Hibiscus rosa-sinensis belonging to the family Malvaceae was the most used by $25 \%$ of parturient. It possesses utero-tonic properties due to flavonoids. Nguene et al. in 2015 found similar results in an ethnobotanical study of flavonoid plants. In this study, $\mathrm{Hi}$ biscus-rosa-sinensis was used to facilitate childbirth [19].

\section{Conclusion}

The reported use of utero-tonic plants in pregnant women is an effective practice at the Hospital Laquintinie; this practice is more the responsibility of multiparas and induces dynamic dystocia, a high rate of caesarean section with a bad neonatal state. Given the maternal and foetal complications reported in our study, it is necessary to initiate case-control studies with hibiscus mainly used in our study in order to assess its operability and thus the prevention of uncontrolled issues.

\section{Limits of the Study}

We have not been able to identify all utero-tonic plants of informal use. Such were the case of those in the form of made-up products and the barks and concerned 77 surveyed.

The concept of utero-tonic plants was declarative and therefore subjective, which could lead to over or underestimation of the effect.

The dosage and the dose-effective effect were not analysed in our study. This therefore limits any relevance in the analysis and conclusion.

\section{Acknowledgements}

The authors express their thanks to the administration of Laquintine Hospital as well as to all the maternity staff for all the support given to them during this study.

\section{Conflicts of Interest}

The authors declare no conflicts of interest regarding the publication of this paper.

\section{Authors' Contributions}

Essome collected the data and wrote the article, Mve, Ekono, Nana, Boten, Penda, Tocki, Foumane read and corrected the article and Mboudou corrected and supervised the writing of the article. 


\section{References}

[1] Din, N., Mpondo, E., Dibong, S.D., Kwin, N.F. and Ngoye, A. (2011) Inventory and Identification of Plants Used in the Treatment of Diabetes in Douala Town (Cameroon). European Journal of Medicinal Plant, 1, 60-73. https://doi.org/10.9734/EJMP/2011/273

[2] Adjanohoun, E., EyogMatig, O., Adjanohoun, E., de Souza, S. and Sinsin, B. (1999) La biodiversité face au développement des industries pharmaceutiques africaines. In: Réseau des espèces ligneuses médicinales, Eds., Compte rendu de la première réunion du réseau tenue 15-17 décembre 1999 à la station IITA Cotonou, Bénin, 88-103.

[3] Mills, E., Koren, G. and Perri, D. (2006) Dugoua 11. HerbaI Medicines in Pregnancy \& Lactation. https://doi.org/10.1201/b13984

[4] Jones, T.K. and Lawson, B.M. (1998) Profound Neonatal Congestive Heart Failure Caused by Maternal Consumption of Blue Cohosh Herbal Medication. Journal of Pediatrics, 132, 550-552. https://doi.org/10.1016/S0022-3476(98)70041-1

[5] Lawn, J.E., et al. (2009) Two Million Intrapartum-Related Stillbirths and Neonatal Deaths: Where, Why, and What Can Be Done? International Journal of Gynecology \& Obstetrics, 107, S5-S19. https://doi.org/10.1016/j.ijgo.2009.07.016

[6] Barbelet, S. (2015) Le Giroflier: Historique, description et utilisations de la plante et de son huile essentielle. Thèse de Pharmacie, Université De Lorraine.

[7] N'guessan, K., Zihiri, G.N., N'takpé, K. and Boraud, M. (2010) Des plantes utilisées pour faciliter l'accouchement, en pays Abbey et Kroubou, au sud de la Côte d'Ivoire: Etude ethno-pharmacologique. International Journal of Biological and Chemical Sciences, 4, 1004-1016. https://doi.org/10.4314/ijbcs.v4i4.63039

[8] Mabina, M.H., Pitsoe, S.B. and Moodley, J. (1997) The Effect of Traditional Herbal Medicines on Pregnancy Outcome. The King Edward VIII Hospitalexperience. South African Medical Journal, 87, 1008-1010.

[9] Olusanya, O., Alakija, P. and Inem, V.A. (2010) Non-Uptake of Facility-Based Maternity Services in an Inner-City Community in Lagos, Nigeria: An Observational Study. Journal of Biosocial Science, 42, 341-358. https://doi.org/10.1017/S0021932009990526

[10] Boerma, T. and Baya, S. (1990) Maternal and Child Health in Anethnomedical Perspective: Traditional and Modern Medicine in Coastal Kenya. Health Policy Plan, 5, 347-357. https://doi.org/10.1093/heapol/5.4.347

[11] Sindiga, I. (1995) Towards the Participation of Traditional Birth Attendants in Primary Health Care in Kenya. East African Medical Journal, 72, 459-464.

[12] Flandermeyer, D., Stanton, C. and Armbruster, D. (2010) Uterotonic Use at Home Births in Low-Income Countries: A Literature Review. International Journal of $G y$ necology \& Obstetrics, 108, 269-275. https://doi.org/10.1016/j.ijgo.2009.12.001

[13] Kongnyuy, J., Mlava, G. and van den Broek, N. (2009) Facility-Based Maternal Death Review in Three Districts in the Central Region of Malawi: An Analysis of Causes and Characteristics of Maternal Deaths. Women Health Issues, 19, 14-20. https://doi.org/10.1016/j.whi.2008.09.008

[14] Mbonye, K. (2001) Risk Factors Associated with Maternal Deaths in Health Units in Uganda. African Journal of Reproductive Health, 5, 47-53. https://doi.org/10.2307/3583322

[15] Umeora, U. and Egwuatu, E. (2010) The Role of Unorthodox and Traditional Birth Care in Maternal Mortality. Tropical Doctor, 40, 13-17. 
https://doi.org/10.1258/td.2009.080207

[16] Katsoulis, L.C., Veale, J. and Havlik, I. (2000) The Pharmacological Action of Rhoicissustridentata on Isolated Rat Uterus and Ileum. Phytotherapy Research, 14, 460-462.

https://doi.org/10.1002/1099-1573(200009)14:6<460::AID-PTR616>3.0.CO;2-A

[17] Watcho, P., Ngadjui, E., Alango Nkeng-Efouet, P., Nguelefack, T. and Kamanyi, A. (2009) Evaluation of in Vitro Uterotonic Activities of Fruit Extracts of Ficusasperifolia in Rats. Evidence-Based Complementary and Alternative Medicine, 2011, Article ID: 783413. https://doi.org/10.1093/ecam/nep221

[18] Kidik, M., Ngene, P., Ngoule, C., Mvogo, B., Ndjib, C., Dibong, D. and Mpondo, E. (2015) Caractérisation des plantes médicinales à flavonoïdes des marchés de Douala, Cameroun. International Journal of Biological and Chemical Sciences, 9, 1494-1516. https://doi.org/10.4314/ijbcs.v9i3.32

[19] Ngene, P., Ngoule, C., Kidik, M., Mvogo, B., Ndjib, C., Dibong, D. and Mpondo, E. (2015) Importance dans la pharmacopée traditionnelle des plantes à flavonoïdes vendues dans les marchés de Douala, Cameroun. Journal of Applied Biosciences, 88, 8194-8210. https://doi.org/10.4314/jab.v88i1.6

[20] Farnsworth, N.R., Akerele, O., Bingel, A.S., Soejarto, D.D. and Guo, Z. (1986) Place des plantes médicinales dans la thérapeutique. Bulletin de IOMS, 64, 159.

[21] Titilayo, K., Rasaq, A. and Ismail, M. (2009) Attitude and Use of Herbal Medicines among Pregnant Women in Nigeria. BMC Complementary and Alternative Medicine, 9, 53. https://doi.org/10.1186/1472-6882-9-53

[22] Mothupi, M.C. (2014) Use of Herbal Medicine during Pregnancy among Women with Access to Public Healthcare in Nairobi, Kenya: A Cross-Sectional Survey. BMC Complementary and Alternative Medicine, 14, 432. https://doi.org/10.1186/1472-6882-14-432

[23] Nyeko, R., Mbona, N. and Abdullah, A.H. (2016) Prevalence and Factors Associated with Use of Herbal Medicines during Pregnancy among Women Attending Postnatal Clinics in Gulu District, Northern Uganda. BMC Pregnancy and Childbirth, 16, 296. https://doi.org/10.1186/s12884-016-1095-5

[24] Aka, E., Horo, A., Koffi, A., Fomba, M., Konan, J.M.P., Fanny, M., Toure, E. and Mamourou, K. (2016) Ocytocique traditionnel: Impact sur le déroulement du travail et l'accouchement sur une cohorte de 210 femmesà la maternité du CHU De Yopougon à Abidjan. Revue Internationale des Sciences Médicales d'Abidjan, 18, 224-229.

[25] Dika, H., Dismas, M., Iddi, S. and Rumanyika, R. (2017) Prevalent Use of Herbs for Reduction of Labor Duration in Mwanza Tanzania: Are Obstetrician Aware? Tanzania Journal of Health Research, 19, 1-8.

[26] KamatenesiMugisha, M. and OryemOriga, H. (2007) Medicinal Plants Used to Induce Labor during Childbirth in Western Uganda. Journal of Ethnopharmacology, 109, 1-9. https://doi.org/10.1016/j.jep.2006.06.011

[27] Furnham, A. (1996) Why Do People Choose and Use Complementary Therapies? In: Ernst, E., Ed., Complementary Medicine: An Objective Appraisal, ButterworthHeinemann, Oxford, 71-88.

[28] Azriani, A.R., Siti, A.S., Zulkifli, A., Wan, N.W. and Abdul, M. (2008) Prevalence and Pattern of Use of Herbal Medicines during Pregnancy in Tumpat District, Kelantan. Malays. Journal of Medical Sciences, 15, 40-48.

[29] M'soka, N.C., Mabuza, L.H. and Pretorius, D. (2015) Cultural and Health Beliefs of Pregnant Women in Zambia Regarding Pregnancy and Child Birth. Curationis, 38, 1-7. https://doi.org/10.4102/curationis.v38i1.1232 
[30] Rolanda, V.D.K. and Sally, T. (2006) Traditional Medicine in Late Pregnancy and Labor: Perceptions of Kgaba Remedies amongst the Tswana in South Africa. African Journal of Traditional, Complementary and Alternative Medicines, 3, 11-22. https://doi.org/10.4314/ajtcam.v3i1.31135

[31] Ezechi, O.C., Mabayoje, P. and Obiesie, L.O. (2004) Ruptured Uterus in South Western Nigeria: A Reappraisal. Singapore Medical Journal, 45, 113-116.

[32] Guerrier, G., Oluyide, B., Keramarou, M. and Grais, R. (2013) High Maternal and Neonatal Mortality Rates in Northern Nigeria: An 8-Month Observational Study. International Journal of Women's Health, 5, 495-499. https://doi.org/10.2147/IJWH.S48179

[33] Jonsson, M. (2009) Use and Misuse of Oxytocin during Delivery. Acta Universitatis Upsaliensis.

[34] N’Guessan, K., Kadja, B., Zirihi, G., Traoré, D. and Aké-Assi, L. (2009) Screening phytochimique de quelques plantes médicinales ivoiriennes utilisées en pays Krobou (Agboville, Côte-d'Ivoire). Sciences \& Nature, 6, 1-15. https://doi.org/10.4314/scinat.v6i1.48575

[35] Gruber, C.W. and O’Brien, M. (2011) Uterotonic Plants and Their Bioactive Constituents. Planta Medica, 77, 207-220. https://doi.org/10.1055/s-0030-1250317 